\title{
Potensi jerami sebagai pakan ternak ruminansia
}

Yanuartono, Hary Purnamaningsih, Soedarmanto Indarjulianto dan Alfarisa Nururrozi,

Departemen Ilmu Penyakit Dalam, Fakultas Kedokteran Hewan Universitas Gadjah

Mada. Jl. Fauna No.2, Karangmalang, Depok, Sleman. 55281 Yogyakarta

Tel : +62-274-560862, Fax +62-274-560861

\section{Correspondence author : yanuartono20@yahoo.com}

\begin{abstract}
The basic reason for poor performance of livestock in developing countries includes Indonesia, is qualitative fluctuations in the feed. Therefore knowledge in utilizing agroindustry byproduct as feedstuff to meet the nutrient requirement of animals is important. Rice straw is a crop residue of rice production and can be used as a feed for ruminants because it is easily and cheaply available in many Asian countries. Rice straws have low nutritive value and it is generally limited by several factors such as the low nutritional quality due to high fiber content and lignification process. In Indonesia, rice straw has been widely utilized in livestock feeding systems, thus the need to improve them is imperative as they are an abundant crop residue. Much more attention has been paid to improving its feeding value in order to increase livestock productivity. Many processing methods to improve the nutritive value of rice straw have been investigated. These methods can be classified as physical, chemical or biological. Usually, processing methods improve the nutritive value of straw by increasing its digestible energy content, by increasing feed intake, or by a combination of the two. This paper aims to examine the potential of rice straw as basal feed livestock as well as efforts to improve their nutritional value.
\end{abstract}

Key words: livestock, rice straw, processing methods, nutritional value

\section{PENDAHULUAN}

Jerami padi adalah hasil
samping dari tanaman padi dan digunakan sebagai sumber pakan untuk ternak ruminansia terutama oleh petani skala kecil di negara-negara berkembang, termasuk Indonesia. Di Indonesia, jerami banyak dimanfaatkan sebagai pakan basal ternak ruminansia, pupuk tanaman produksi, karena sangat melimpah serta murah. Pemanfaatan jerami sebagai pakan ternak terutama dilakukan pada saat musim kemarau dimana para peternak sulit untuk memperoleh hijauan berkualitas tinggi (Castillo et al., 1982). Sebagai sumber pakan, jerami mempunyai beberapa kelemahan yaitu kandungan lignin dan silika yang tinggi tetapi rendah energi, protein, mineral dan vitamin. Selain rendah nilai nutrisi, kecernaan jerami juga rendah karena sulit didegradasi oleh mikroba rumen (Van Soest, 2006; Sarnklong et al., 2010). Selain hal tersebut diatas, kelemahan yang lain adalah karena jerami memiliki faktor pembatas seperti zat anti nutrisi (Mathius dan Sinurat, 2001) serta palatabilitasnya rendah (Tillman et al., 1998). Kecernaan yang rendah pada jerami padi merupakan akibat dari struktur jaringan penyangga tanaman yang sudah tua. Jaringan tersebut sudah mengalami proses lignifikasi, sehingga lignoselulosa dan lignohemiselulosa sulit dicerna (Balasubramanian, 2013). 
Berbagai upaya telah dilakukan untuk meningkatkan kualitas jerami padi, baik dengan cara fisi/mekanik, kimia maupun biologis. Upaya upaya tersebut terutama bertujuan untuk meningkatkan nilai nutrisi, palatabilitas dan kecernaan, sehingga diharapkan dapat menjamin ketersediaan pakan secara berkelanjutan. Tulisan ini bertujuan untuk mengkaji potensi jerami jika digunakan sebagai pakan tunggal serta upaya untuk meningkatkan kualitas nilai nutrisinya.

\section{NILAI NUTRISI JERAMI}

Penelitian tentang karakteristik fisika, kimia serta penggunaan jerami padi sebagai pakan basal telah banyak dilakukan dengan hasil yang bervariasi (Abou-El-Enin et al., 1999; Vadiveloo, 2003). Hasil penelitian yang dilakukan oleh santos et al. (2010) dan Peripolli et al. (2016) menunjukkan bahwa nilai nutrisi dari jerami sangat bervariasi. Variasi tersebut kemungkinan disebabkan oleh siklus panen, jumlah produksi beras yang dihasilkan dan waktu pengemasan. Menurut Bainton et al. (1991), varietas tanaman padi juga berpengaruh terhadap kecernaan jerami, namun demikian secara umum varietas tanaman padi produksi tinggi akan lebih banyak menghasilkan pakan jerami setiap hektarnya.

Jerami padi mempunyai karakteristik kandungan protein kasar rendah serta serat kasar yang tinggi antara lain selulosa, hemiselulosa, lignin dan silika ((Greenland, 1984; Lamid, 2013). Menurut Wanapat et al., (2013) kandungan protein kasar pada jerami padi sekitar 2-5\%. Hasil tersebut tidak jauh berbeda dengan penelitian yang dilakukan oleh Modak (1985), maupun data NRC (1980) dengan kandungan protein kasar rata rata 2-5\%. Hasil penelitian kandungan protein kasar jerami padi di Indonesia juga menunjukkan hasil bervariasi. Menurut Syamsu et al. (2006), jerami padi yang berasal dari Sulawesi Selatan mengandung protein kasar sebesar 4,31\%, Aceh 4,90\% (Hanum dan Usman, 2011), Mataram, Lombok 4,74\% (Amin et al., 2015), Bali 3,45\%. (Trisnadewi et al., 2011). Namun demikian, hasil penelitian yang dilakukan oleh Manurung dan Zulbardi (1996) menunjukan hasil yang berbeda karena kadar protein kasar cukup tinggi yaitu sebesar 6,34\%.

Rumput rumputan maupun leguminosa menunjukkan kandungan protein kasar yang jauh lebih tinggi jika dibandingkan dengan jerami padi. Hasil penelitian Odedire and Babayemi (2008) menunjukkan bahwa kandungan protein kasar pada Panicum maximum asal Nigeria adalah sebesar 9,36\%, asal Brazil 12,7\% (Fernandez et al., 2014), asal Bogor $12,75 \%$ (Sajimin et al., 2004). Sedangkan pada leguminosa Sesbania grandiflora, protein kasar menunjukkan kandungan sebesar 49,77 pada daun segar (Rusdi et al., 2007), 30,00\% tepung daun (Firmani et al., 2015). Hasil penelitian oleh Chellapandian et al. (2016) menunjukkan kadar protein kasar Sesbania grandiflora yang lebih rendah yaitu 34,56\%. Sedangkan kandungan protein kasar leguminosa Indigofera arrecta 24,6\% (Hassen et al., 2007), Leucaena leucocephala $24 \%$ (Masama et al., 1997).

Hasil hasil penelitian dari berbagai negara dan wilayah di Indonesia menunjukkan bahwa kadar protein kasar pada jerami menunjukkan kisaran angka 3-5\%. Hal tersebut menunjukan bahwa pada kenyataanya kadar protein kasar jerami adalah sangat rendah jika dibandingkan dengan hijauan pakan ternak seperti rumput rumputan dan leguminosa. Dengan demikian, perlu dilakukan pengolahan melalui berbagai metode untuk meningkatkan kualitas jerami melalui peningkatan kadar protein kasar tersebut. 
Kandungan Neutral Detergent Fiber (NDF) jerami padi yang tinggi mengakibatkan sulit untuk dicerna. Hasil penelitian Syamsu et al. (2013) menunjukkan bahwa kandungan NDF dalam jerami sebesar $72,52 \%$. Menurut Shen et al. (1998), meskipun tidak banyak selisihnya, tetapi kandungan NDF dipengaruhi oleh musim panen. Kandungan NDF tertinggi $(72,53 \%)$ terdapat pada awal musim panen, sedangkan terendah $(70,03 \%)$ terdapat pada pertengahan musim panen. Kandungan NDF pada jerami asal Selangor, malaysia menunjukkan kandungan NDF sebesar 82,98\% (Jahromi et al., 2010) Iran 68,95\% Jafari et al. (2007), Kandungan NDF jerami dari tanaman padi asal Jawa Tengah, Indonesia menunjukkan kadar yang tinggi, yaitu 80,59\% (Anam et al., 2012), sedangkan jerami padi asal mataram, Indonesia menunjukkan kandungan 75,94\%. Penelitian oleh Trisnadewi et al. (2011) pada jerami padi di Bali menunjukkan kandungan NDF jerami sebesar 79,80\%. Jerami padi dari semua wilayah dan berbagai negara menunjukkan kandungan NDF yang tinggi, mulai dari $68,95 \%$ sampai $80,59 \%$. Kandungan NDF berhubungan erat dengan konsumsi pakan, sebab seluruh komponennya memenuhi rumen dan lambat dicerna, sehingga semakin rendah kandungan NDF dalam pakan akan semakin mudah terkonsumsi. Tanaman hijauan pakan ternak seperti rumput raja memiliki kandungan NDF sebesar 59,70\% (Yulianti, 2010), Panicum maximum 66,84\%, Pennisetum purpureum 66,96\% (Nasrullah et al., 2003), Sesbania grandiflora 45,11\% (Hau et al., 2005), Calliandra calothyrsus 31,03\%, Centrosema pubescens 56,81\%, Gliricidia maculata 32,97\%, Leucaena leucocephala 31,67\% (Nasrullah et al., 2003). Dibandingkan dengan kandungan NDF pada hijauan tersebut diat- as, baik rumput rumputan maupun leguminosa maka jerami padi memiliki kandungan NDF yang jauh lebih besar.

Selain limbah jerami padi, terdapat beberapa limbah tanaman yang dapat dimanfaatkan sebagai pakan ternak. Limbah tersebut memiliki kandungan NDF yang bervariasi mulai dari yang lebih rendah, sama atau bahkan lebih tinggi dibandingkan dengan kandungan NDF pada jerami padi. Sebagai contoh, limbah jerami jagung yang mengandung NDF sebesar 46,55\% (Paath et al., 2012), akan tetapi penelitian lain menunjukkan bahwa kandungan NDF limbah jerami jagung memiliki kisaran angka yang sama yaitu 71,93\% (Li et al., 2014). Hasil penelitian kandungan NDF pada limbah kelapa sawit juga cukup bervariasi, meskipun semua menunjukkan angka yang tinggi, yaitu 75,4\% (Winugroho, 1999) dan 84,6\% (Jalaludin, 1994). Secara garis besar dapat dilihat bahwa kandungan NDF pada jerami padi jauh lebih tinggi dibandingkan dengan rumput rumputan maupun leguminosa namun sama, lebih rendah atau lebih tinggi jika dibandingkan dengan limbah tanaman lain. Oleh sebab itu, penelitian penelitian pada jerami untuk meningkatkan nilai nutrisinya banyak difokuskan pada pengolahan guna menurunkan kandungan NDF dalam jerami.

Engsminger and Olentine (1980) menyatakan bahwa acid detergent fiber (ADF) dapat digunakan untuk memperkirakan kecernaan bahan kering dan energi makanan ternak. ADF ditentukan dengan menggunakan larutan Detergent Acid, dimana residunya terdiri atas selulosa dan lignin. Semakin tinggi nilai ADF, maka kualitas daya cerna hijauan makanan ternak semakin rendah (Crampton and Haris, 1969). Menurut Arora (1989), rendahnya kualitas daya cerna jerami padi disebabkan karena ADF mengandung $15 \%$ pentosa yang 
disebut micellar pentosa yang sulit dicerna dibandingkan dengan jenis karbohidrat lainnya. Pentosa adalah campuran araban dan xilan dengan zat lain dalam tanaman yang dalam hidrolisis keduanya menghasilkan arabinose dan xilose yang ditemukan dalam hemiselulosa.

Hasil penelitian Antonius (2009) menunjukkan bahwa jerami padi mengandung ADF 46,72\% dari bahan kering. Penelitian oleh Yanuarianto et al. (2015) di Mataram menunjukkan kandungan ADF jerami padi sebesar $52,01 \%$, sedangkan asal Jawa Tengah menunjukkan nilai sebesar 60,57\% (Anam et al., 2012). Penelitian kandungan ADF jerami padi asal Thailand oleh Wanapat et al. (2013) menunjukkan nilai sebesar $63,7 \%$ dan asal Turki sebesar 41,15\% (Selçuk et al., 2016). Kandungan ADF yang cukup rendah yaitu $40,95 \%$ ditunjukkan oleh hasil penelitian jerami padi di Cina (Yuan et al., 2016). Kisaran nilai ADF pada penelitian-penelitan diatas adalah 40,95$63,7 \%$, sehingga dapat dikatakan bahwa kandungan ADF pada jerami padi adalah tinggi jika dibandingkan dengan hijauan pakan ternak yang lain.

Hasil penelitian Aganga dan Tshwenyane (2004) menunjukkan bahwa kandungan ADF pada berbagai kultivar Panicum maximum memiliki kisaran $25-35,3 \%$. Penelitian oleh Relling et al. (2001) pada Panicum maximum kultivar Gatton pada musim panas mengandung ADF sebesar 28,90\%. Namun demikian, beberapa hasil penelitian oleh menunjukan bahwa kandungan ADF pada Panicum maximum menunjukkan nilai yang cukup tinggi yaitu $44,01 \%$ (Rahalus et al., 2014) dan 46,85\% (Ansah et al., 2010). Kandungan ADF pada Pennisetum purpureum juga memiliki angka yang cukup tinggi yaitu sebesar 47,18\% (Ukanwoko and Igwe, 2012) dan
42,62\%. (Muhakka et al., 2014). Sedangkan kandungan ADF pada beberapa leguminosa memiliki nilai yang lebih rendah, seperti Sesbania grandiflora 21,99\%, Leucaena leucocephala 22,97\% (Sudirman et al., 2015), Centrosema pubescens 37,11\% (Ukanwoko and Igwe, 2012) dan Gliricidia sepium 25,43\%, (Filho et al., 2016). Penelitian Kandungan ADF pada Calliandra calothyrsus dari berbagai negara oleh Premaratne and Perera (1999) menunjukkan hasil yang bervariasi mulai dari 21,10- 26,32\%. Kandungan ADF pada jerami padi jika dibandingkan dengan limbah tanaman yang lain seperti jagung dan limbah tebu juga masih lebih tinggi. Limbah tanaman jagung mengandung ADF $32,64 \%$ (Sudirman dan Imran 2007) dan limbah tebu 48,96\% (Wati et al., 2012). Namun demikian, kandungan ADF pada jerami padi hampir sama tingginya dengan ADF limbah kelapa sawit yang memiliki angka sebesar 66,5\% (Jalaludin, 1994). Hasil penelitian diatas menunjukkan bahwa kandungan ADF pada jerami relatif lebih tinggi dibandingkan dengan rumput rumputan, leguminosa dan bahkan sebagian limbah hijauan yang lain. Meskipun demikian, beberapa limbah tanaman seperti tebu dan kelapa sawit memiliki kandungan ADF yang sama tingginya. Dengan demikian, kualitas limbah tanaman tebu dan sawit memiliki kualitas yang sama rendahnya dengan jerami.

Jerami memiliki kandungan mineral yang cukup lengkap seperti Phosphorus (P), Potassium (K), Zink (Zn), Sulphur (S), Silicon (Si), Magnesium (Mg), Calcium (C), Iron (Fe), Manganese $(\mathrm{Mn})$, Copper $(\mathrm{Cu})$ dan Boron (B) (Ismail et al., 2013). Namun demikian, menurut White and Hembry (1985), jerami memiliki kandungan Ca dan $\mathrm{P}$ rendah, kadar abu tinggi dengan komponen utama silika. Shen et al. 
(1998) menunjukkan bahwa kandungan mineral pada jerami tergantung pada musim panen. Kandungan $\mathrm{K}$ dan $\mathrm{Mg}$ yang paling tinggi terdapat dalam jerami pada awal musim panen $(2,21 \%$ dan $0,91 \%$ dari bahan kering). Sedangkan menurut Little (1986), kandungan mineral $\mathrm{Ca}$ dan $\mathrm{S}$ pada jerami padi di Indonesia berturut-turut yaitu 1.5 dan 1.2, $\mathrm{mg} / \mathrm{kg}$ bahan kering. Meskipun kandungan mineral pada jerami padi cukup lengkap namun secara umum relatif lebih rendah jika dibandingkan dengan kandungan mineral pada rumput rumputan maupun leguminosa. Pakan kualitas rendah yang memiliki kandungan tinggi serat kebanyakan mengandung mineral yang sangat rendah sehingga menjadi faktor pembatas pertumbuhan mikroba dalam rumen seperti P dan S ( Preston and Leng, 1987 ; Komisarczuk and Durand, 1991). Oleh sebab itu, perlu diberikan tambahan mineral pada ransum ternak jika jerami padi digunakan sebagai pakan utama. Penelitian Yanuartono et al. (2016) menunjukkan bahwa penambahan molasses mineral blok pada sapi potong yang diberikan pakan basal jerami mampu meningkatkan pertambahan bobot yang lebih besar jika dibandingkan dengan sapi yang hanya mengonsumsi jerami.

\section{FAKTOR PEMBATAS NUTRISI JERAMI}

Keterbatasan penggunaan jerami padi sebagai pakan ternak disebabkan karakteristik dinding selnya yang berbeda dari dinding sel jerami tanaman sereal lainnya. Jerami Padi mengandung tiga komponen fraksi serat yaitu selulosa, hemiselulosa dan lignin. Disamping ketiga komponen fraksi serat tersebut, jerami padi juga mengandung silika (Howard et al., 2003). Menurut Reddy and Yang (2006), komposisi fraksi serat jerami padi terdiri dari $40 \%$ selulosa, $30 \%$ hemiselulosa, $15 \%$ silika dan $15 \%$ lignin. Sebagai limbah tanaman tua, jerami padi telah mengalami lignifikasi lanjut, menyebabkan terjadinya ikatan kompleks antara lignin, selulosa dan hemiselulosa (lignoselulosa) (Eun et al., 2006). Faktor-faktor tersebut diatas merupakan pembatas dalam pemanfaatan jerami padi.

Jerami padi memiliki kandungan silika yang bervariasi dengan kisaran nilai sekitar $60 \%$ (Khorsand et al., 2012). Variasi kandungan tersebut tergantung dari musim, jenis tanah, waktu panen dan kondisi geografis (Santos et $a l ., 2010)$. Kandungan silika dalam jerami padi

dapat mencapai 19,2\% dari bahan kering (Chairunnisa et al., 2013), 15\% (Sarnklong et al., 2010), 13,94\% (Binod et al., 2010), 11\% (Phutela, 2011), 10,7\% (Marxen et al., 2016), 7,12\% (Antonius, 2010). Menurut Van Soest (1983) setiap kenaikan 1\% kadar silika bahan akan menurunkan kecernaan sebesar 2 - 3\% pada rruminansia. Silika menurunkan palatabilitas dan penguraian jerami padi dalam rumen karena aksi langsung dalam mencegah kolonisasi oleh mikroorganisme rumen (Agbagla-Dohnani et al., 2003).

Lignin pada jerami padi merupakan polimer poli aromatik dengan berat molekul tinggi dan termasuk golongan phenolik lignin yang tahan terhadap hidrolisis enzimatik termasuk fermentasi oleh mikroba rumen dan alkali tanah (Hatakka, 2000; Ghaffar and Fan, 2014). Lignin berperan dalam menguatkan tumbuhan secara mekanis serta resistensi terhadap degradasi mikroba dalam rumen (Vanholme et al., 2010). Senyawa fenolik yang terkandung dalam lignin berperan dalam pertahanan fisik dan memiliki peran antinutrisi (Antongiovanni and Sargentini, 1991). Kompleksnya komponen lignin mengakibat- 
kan sulit didegradasi sehingga dibutuhkan komponen enzim selulase, hemiselulase dan ligninase untuk memecahnya (Schiere and Ibrahim, 1989). Kandungan lignin dalam jerami padi menurut hasil penelitian Rahnama et al. (2013) adalah 9,22\%. Sedangkan kandungan lignin jerami padi pada penelitian lain menunjukkan hasil bervariasi, sebagai contoh $6,00 \%$ (Kaur and Phutela, 2014) 6,70\%, (Prihartini et al., 2011), 12,00\% (Kargbo et al., 2009), 12,5\% (Karimi et al., 2006), 16,62\% (Dewi, 2002), 26,63\% (Harun and Geok, 2016) 30,14\% (Amin et al., 2015).

Secara umum, kandungan lignin pada jerami padi berkisar antara 6,00 30,14\%. Lignin dan silika pada jerami padi merupakan penghalang utama pemanfaatannya sebagai pakan pada ruminansia (Van Soest, 2006). Oleh sebab itu sebenarnya jerami padi lebih tepat digunakan sebagai bahan bakar jika dibandingkan dengan sumber pakan ternak (Binod et al., 2010; Harun and Geok, 2016). Dengan demikian, jika akan dimanfaatkan sebagai pakan ternak maka pengolahan limbah jerami padi terutama ditujukan untuk menurunkan kandungan faktor faktor pembatas tersebut diatas sehingga mikroba dalam rumen akan mampu memanfaatkan secara maksimal jerami padi tersebut.

\section{METODE PENINGKATAN NILAI NUTRISI JERAMI}

Pada dasarnya, kunci untuk meningkatkan nilai nutrisi jerami padi untuk ternak ruminansia adalah mengatasi hambatan proses fermentasi mikroba dalam rumen. Banyak penelitian telah dilakukan selama beberapa dekade yang bertujuan untuk meningkatkan nilai gizi dari jerami padi, dengan tingkat keberhasilan yang beragam (Selim et al., 2004; Sarnklong et al., 2010). Usaha peningkatan kualitas jerami padi tersebut dilakukan dengan cara meningkatkan nilai cernanya melalui pemecahan ikatan kompleks lignoselulosa baik secara mekanik/ fisik (Sarwar et al., 2004), kimia dan biologis maupun kombinasinya (Doyle et al., 1996). Metode metode tersebut diatas secara umum digunakan untuk melemahkan dan memecah ikatan ligno-selulosa pada jerami, sehingga nilai nutrisi akan meningkat (Malik et al., 2015). Namun demikian, dipandang dari sisi efisiensi, pengolahan tersebut akan selalu dikaitkan dengan biaya dari setiap metode yang digunakan sehingga tidak semua metode dapat diterapkan di peternakan rakyat.

Metode mekanik/fisik, kimia, dan biologis merupakan dasar dari metode pengolahan jerami. Metode mekanik/ fisik yang sering digunakan pada jerami padi adalah pemotongan, pencacahan dan penggilingan karena metode tersebut dapat dikerjakan dengan mudah dan dengan biaya yang rendah. Metode kimia yang digunakan dalam pengolahan jerami adalah perlakuan dengan senyawa alkali, asam dan reagen oksidatif (Doyle et al., 1996). Sedangkan metode biologis yang digunakan untuk meningkatkan nilai nutrisi jerami padi adalah pembuatan kompos, fermentasi dengan pemberian enzim, bakteri maupun fungi. Penggunaan jamur dan enzim yang memiliki kemampuan memetabolisme lignoselulosa berpotensi meningkatkan nilai gizi jerami padi melalui mekanisme delignifikasi yang selektif (Liu and Orskov, 2000). Ketiga metode tersebut merupakan dasar metode pengolahan limbah yang kemudian oleh para peneliti dikembangkan lebih lanjut menjadi bervariasi. Metode yang populer dan telah diterapkan karena dapat diaplikasikan dilapangan dengan mudah dan biaya murah adalah fermentasi (Seglar, 2003; Zakaria et al., 2013) 
dan amoniasi (McDonald et al., 2002; Tanuwiria et al., 2005; Bata, 2008).

Metode perlakuan fisik seperti pemotongan dan pencacahan tidak mempengaruhi komposisi kimiawi dari jerami padi. Tujuan dari pemotongan adalah menurunkan jumlah materi yang tidak berguna dan mempermudah pengunyahan oleh ruminansia (Minson, 1963). Sedangkan pencacahan bertujuan untuk meningkatkan nilai nutrisi, asupan serta kecepatan melewati saluran pencernaan. Metode perlakuan fisik lain yang digunakan dalam meningkatkan nilai nutrisi jerami padi adalah perendaman, dibentuk pellet, pengukusan, pressure cooking dan penggunaan sinar $\mathrm{X}$. Namun demikian, perlakuan tersebut sulit untuk diterapkan dalam skala kecil karena tidak praktis dengan biaya yang sangat mahal (Schiere dan Ibrahim, 1989). Namun disisi lain perlakuan fisik seperti pemotongan dan pencacahan dinilai kurang menguntungkan, karena dengan mengecilnya ukuran partikel menyebabkan laju aliran pakan dalam rumen ternak meningkat sehingga kecernaanya menurun (Doyle et al., 1996). Hasil penelitian Zhaoa et al. (2009) menunjukkan bahwa ukuran partikel jerami padi berpengaruh besar terhadap aktivitas mengunyah, kecernaan serat, $\mathrm{pH}$ rumen. Namun demikian, ukuran partikel hanya memiliki pengaruh yang kecil terhadap konsumsi pakan, laju aliran pakan dalam duodenum dan ileum, rumen dan jumlah cerna saluran, dan fermentasi dalam rumen. Merujuk pada hasil penelitian penelitian diatas, tampaknya metode perlakuan fisik/mekanik lebih tepat digunakan sebagai metode awal sebelum dilanjutkan menuju perlakuan kimia maupun biologis.

Agen alkali yang paling umum dan paling sering digunakan adalah natrium hidroksida $(\mathrm{NaOH})$, amonia (NH3), urea, klorin dan kapur. Perla- kuan kimia pada jerami padi tampaknya menjadi metode yang praktis untuk digunakan pada peternakan skala kecil menengah, karena aplikasinya sederhana dan tidak memerlukan teknologi yang mahal (Van Soest 2006; Sarnklong et al., 2010). Meskipun perlakuan kimia dinilai lebih prospektif, karena senyawa-senyawa kimia yang digunakan dapat bekerja dengan cepat, namun penggunaan bahan bahan kimia tersebut memiliki banyak kelemahan (Doyle, 1996). Kelemahan dari penggunaan bahan bahan kimia tersebut antara lain, sulit didapat dikalangan petani, harga yang mahal, penggunaan yang tidak tepat akan mengakibatkan dampak negatif pada ternak (Ali,1998).

Salah satu metode perlakuan secara kimia adalah delignifikasi dengan menggunakan $\mathrm{NaOH} / \mathrm{KOH}$ karena kemampuannya merusak struktur lignin, bagian kristalin dan amorf, memisahkan sebagian lignin dan hemiselulosa serta menyebabkan penggembungan struktur selulosa (Marsden dan Grey, 1986; Gunam dan Antara 1999). Metode perlakuan tersebut juga akan meningkatkan efektifitas proses hidrolisis enzimatis dengan cara meningkatkan aksesibilitas enzim pada permukaan selulosa. Dampak yang ditimbulkan dari perlakuan alkali tersebut memungkinkan mikroorganisme rumen lebih mudah mengurai struktur karbohidrat dan meningkatkan palatabilitas jerami padi (Selim et al., 2004). Meskipun memiliki dampak yang menguntungkan, namun perlakuan dengan $\mathrm{NaOH}$ juga memiliki dampak yang tidak diinginkan berupa peningkatan kecepatan melintas pakan dalam rumen dan urinasi yang berlebihan (Van Soest, 2006; Sarnklong et al., 2010). Dampak merugikan lain yang timbul adalah limbah cair yang berasal dari proses tersebut akan terkontaminasi dengan sisa $\mathrm{NaOH}$ dan dapat mengaki- 
batkan pencemaran lingkungan (Fahey et al., 1993).

Amoniasi merupakan salah satu perlakuan kimiawi yang sangat populer dilakukan untuk meningkatkan kualitas nutrisi jerami padi. Amoniasi merupakan salah satu perlakuan kimia yang bersifat alkalis dan dapat melarutkan hemiselulosa, lignin dan silika, saponifikasi asam uronat dan ester asam asetat, menetralisasi asam nitrat bebas serta mengurangi kandungan lignin dinding sel. Turunnya kristalinitas selulosa akan memudahkan penetrasi enzim selulosa mikrobia rumen (Van Soest, 1982). Hasil penelitian Sudana (1984) menunjukkan bahwa jerami padi yang diberi perlakuan urea $4 \%$ dan disimpan selama 4 minggu terjadi peningkatan daya cerna dari $35 \%$ menjadi $43,6 \%$ dan kandungan nitrogen total dari $0,48 \%$ menjadi $1,55 \%$. Hasil penelitian perlakuan kimiawi yang lain menunjukkan bahwa pemberian $20 \mathrm{~g} / \mathrm{kg}$ urea $+20 \mathrm{~g} /$ $\mathrm{kg}$ kalsium hidroksida dalam jerami padi mampu meningkatkan nilai gizi jerami padi seperti peningkatan asupan bahan kering, daya cerna, asam lemak volatil rumen, populasi bakteri dan jamur, retensi nitrogen dan sintesis protein mikroba (Polyorach and Wanapat, 2015).

Perlakuan biologis dengan menggunakan bakteri, jamur atau enzim ditujukan untuk menghidrolisis bahanbahan berselulosa agar nilai nutrisinya meningkat dan bisa digunakan untuk pakan atau menghasilkan bahan yang bisa dipakai untuk fermentasi selulosa menjadi protein (Soenarjo et al., 1991). Penggunaan bakteri dan jamur untuk mendegradasi selulosa dari jerami padi mengacu pada kemampuan mikroorganisme yang terdapat dalam rumen. Menurut Dijkstra and Tamminga (1995), dinding sel tanaman dapat didegradasi oleh kombinasi bakteri, jamur dan protozoa. Kontribusi aktivitas degradasi oleh jamur dan bakteri sekitar $80 \%$, sedangkan protozoa $20 \%$. Pengolahan jerami padi pada skala peternakan kecil dan menengah dengan menggunakan metode biologis memiliki potensi lebih besar untuk dikembangkan secara luas jika dibandingkan dengan penggunaan bahan kimia yang mahal. Dengan demikian, metode perlakuan biologis dengan menggunakan jamur atau enzim untuk meningkatkan kecernaan jerami padi merupakan alternatif yang menjanjikan. Keuntungan dari perlakuan biologis seperti murah, kebutuhan energi yang rendah dan hanya sedikit berpengaruh terhadap kondisi lingkungan sehingga pencemaran dapat diminimalisir (Saratale et al., 2008). Saat ini telah tersedia produk komersial enzim yang berasal dari Trichoderma longibrachiatum, Aspergillus niger dan A. oryzae untuk kepentingan industri pakan ternak (Rodrigues et al., 2008).

Metode fermentasi jerami merupakan salah satu cara pengolahan yang relatif murah, praktis dan hasilnya cukup disukai ternak. Istilah fermentasi sendiri adalah segala macam proses metabolik dengan bantuan enzim dari mikroba untuk melakukan oksidasi, reduksi, hidrolisa, dan reaksi kimia lainnya (Stanbury and Whitaker, 1984). Proses fermentasi terjadi akibat kinerja dari berbagai macam bakteri pengurai seperti selulolitik, lignolitik, lipolitik dan/atau bahan-bahan yang bersifat fiksasi nitrogen non simbiotik. Sebagai contoh, bakteri selulolitik yang dapat digunakan dalam proses fermentasi adalah Actinobacillus sp (Mirni et al., 2006), Cytophaga hutchinsoi, Acidothermus cellulyticus, (Mirni et al., 2011), Bacillus sp., Pseudomonas sp. dan Serratia sp (Khatiwada et al., 2016). Sedangkan bakteri lignolitik yang dapat digunakan untuk perlakuan fermentasi adalah Bacillus sp. (AbdElsalam and El-Hanafy, 2009), Pantoea 
sp (Xiong et al., 2013), Bacillus pumilus strain B37 (Kausar et al., 2012).

Hasil penelitian Soepranianondo et al. (2007) menunjukkan bahwa pemberian jerami padi yang diamoniasi dan difermentasi pada domba menggunakan suspensi bakteri selulolitik menunjukkan perbedaan yang nyata terhadap terhadap pertambahan berat badan dan angka konversi pakan meskipun tidak menunjukkan perbedaan yang nyata terhadap konsumsi bahan kering pakan. Bakteri yang digunakan dalam penelitian tersebut adalah suspensi bakteri Acetobacter liquefaciens dan campuran suspensi bakteri Acidophilium facilis, Acetobacter liquefaciens, Cellulomonas sp. dan Acenitobacter sp. Sedangkan hasil penelitian fermentasi jerami padi oleh Li et al. (2010) dengan menggunakan Lactobacillus plantarum dengan penambahan glukosa menunjukkan terjadinya peningkatan nilai nutrisinya. Kombinasi bakteri Clostridium sp., Bacillus sp., dan Geobacillus sp yang digunakan pada proses fermentasi selama 9 hari mampu mengurai kandungan lignoselulose dalam jerami padi (Zhao et al., 2014).

Saat ini, telah banyak mikroflora dengan kemampuan untuk mendegradasi jerami padi berhasil diisolasi yang sebagian besar berasal dari tanaman in vitro. Beberapa jamur yang hidup di tanah memiliki kemampuan untuk mendegradasi senyawa lignin dan selulosa. Jamur tersebut menghasilkan ligninase yang dapat mendegradasi senyawa lignin dan selulase yang dapat mendegradasi selulosa. Contoh dari jamur tersebut adalah adalah Fusarium proliferatum, Peniciilium decumbens (Yang et al., 2005) dan Penicillium simplicissimum (Zeng et al., 2006). Sedangkan contoh jamur yang mampu mendegradasi selulosa adalah Aspergillus niger, Chaetomium globosum, Scopulariopsis brevicaulis,
Trichoderma koningii, Trichoderma roseum, dan Mucor hiemalis (Lakshmikant 1990; Mahmood et al., 2006). Penelitian oleh Helal (2006) dengan menggunakan jamur Aspergillus ochraceus, A. Terreus dan Trichoderma koningii untuk fermentasi menunjukan adanya peningkatan nilai protein kasar pada jerami padi. Isolat Trichoderma viride F94 dan Aspergillus terreus F98 dapat digunakan juga untuk degradasi selulosa pada jerami padi (Abo-State et al., 2014).

Secara garis besar, metode perlakuan tersebut biasanya hanya sebatas meningkatkan asupan dan kecernaan bahan akan tetapi masih tidak mampu mengatasi ketidak seimbangan nutrisi yang terkandung di dalamnya. Dengan demikian, guna mengoptimalkan penggunaan jerami padi, selain dilakukan dengan berbagai macam perlakuan, juga diperlukan pemberian feed suplemen seperti konsentrat (Mayulu et al., 2013; Mulijanti et al., 2014), molasses (Manurung dan Zulbardi, 1996; Bata dan Nur Hidayat, 2010; Alam et al., 2016) dan UMMB (Astutik et al., 2002; Yanuartono et al., 2016), guna membantu peningkatan pertumbuhan mikroba rumen, karena kecernaan serat pada ternak rumunansia sangat tergantung pada enzim-enzim yang dihasilkan oleh mikroba rumen.

Penelitian metode kombinasi mekanik/ fisik, kimia, dan biologis untuk meningkatkan nilai nutrisi jerami telah banyak dilakukan. Hasil penelitian Yanuarianto et al. (2015) menunjukkan terjadinya penurunan secara nyata jerami padi yang difermentasi dengan kombinasi Bacillus sp., $\mathrm{CaCO}_{3}$ dan air kelapa terhadap kandungan serat kasar dan komponen serat seperti NDF, ADF, hemisellulosa, selulosa dan lignin. Hasil yang sama juga ditunjukkan oleh penelitian Amin et al. (2015) pada jerami padi yang diberi perlakuan biologis 
dengan fermentasi serta perlakuan kimia dengan amonia mampu menurunkan nilai NDF, ADF, selulosa dan lignin. Penelitian menggunakan perlakuan kombinasi pencacahan dengan fermentasi menggunakan jamur Coprinus comatus mampu meningkatkan nilai nutrisi

jerami padi yang diberikan pada domba (Mustabi et al., 2013). Pada dasarnya, kandungan selulosa dalam jerami padi tidaklah murni akan tetapi selalu terkait dengan lignin, hemiselulosa dan silika. Oleh sebab itu, secara alami selulosa tidak mudah diurai oleh mikroba (Helal, 2005). Perlakuan dengan metode mekanik/fisik atau kimia dan/atau metode biologis memiliki kemampuan sebatas merubah struktur lignoselulosa atau kompleks lignin-hemiselulosa selulosa (LHC). Metode tersebut pada umumnya digunakan untuk memfasilitasi pertumbuhan jamur yang memiliki kemampuan aktivitas selulolitik tinggi (Helal, 2005).

Berbagai macam kombinasi perlakuan dapat dilakukan guna meningkatkan nilai nutrisi jerami. Kombinasi tersebut antara lain adalah fisik/mekanik-kimia, fisik mekanikbiologis dan fisik/mekanik-kimiabiologis. Perlakuan kombinasi pada jerami padi yang menjadi pilihan terbaik adalah perlakuan dengan dampak tingkat kerusakan serta hilangnya nutrisi minimal untuk kemudian menghasilkan substrat terbaik untuk hidrolisis. Hasilhasil penelitian menunjukkan bahwa perlakuan kombinasi pada jerami padi memiliki kemampuan yang lebih besar dalam meningkatkan nilai nutrisi dibandingkan dengan metode perlakuan tunggal.

\section{JERAMI SEBAGAI PAKAN BASAL TUNGGAL}

Jerami padi tidak mengandung cukup glukosa, asam amino dan mineral untuk pertumbuhan mikroba dalam rumen (Doyle et al., 1996). Selain kelemahan tersebut diatas, jerami padi memilik sifat tinggi serat kasar, nitrogen rendah dan komposisi mineral yang tidak seimbang sehingga mengakibatkan asupan rendah. Semua hal tersebut diatas akan mengakibatkan pemberiannya sebagai pakan basal tunggal, baik secara langsung maupun melalui proses perlakuan, tidak akan dapat memenuhi kebutuhan nutrisi pada ternak. Penelitian penelitian yang berhubungan dengan jerami sebagai pakan tunggal telah banyak dilakukan dengan hasil penurunan bobot badan pada ternak kerbau (Zulbardi et al., 1983; Wongsrikeao and Wanapat, 1985), sapi (McLennan et al., 1981) dan domba (Vijchulata and Sanpote, 1982). Penurunan bobot badan yang disebabkan oleh kadar serat kasar dan silika yang terlalu tinggi serta kadar protein dan nilai cernanya yang sangat rendah. Hasil evaluasi yang dilakukan oleh Sarnklong et al. (2010) juga menunjukkan pemberian jerami padi sebagai pakan tunggal tidak memenuhi syarat pemeliharaan pada sapi potong.

\section{KESIMPULAN}

Produksi jerami padi yang melimpah merupakan sumber pakan ternak ruminansia yang cukup menjanjikan. Namun, disebabkan oleh kandungan protein yang rendah serta tingginya silika dan lignin mengakibatkan rendahnya kecernaan pada ruminansia. Nilai nutrisi jerami padi dapat ditingkatkan dengan berbagai metode perlakuan. Meskipun demikian, berbagai metode perlakuan tersebut tampaknya tidak mampu memenuhi kebutuhan basal ternak sehingga tidak dapat digunakan sebagai pakan tunggal kecuali diberikan tambahan pakan dari sumber yang lain.

\section{DAFTAR PUSTAKA}


Abd-Elsalam, H. E., and El-Hanafy, A. A. 2009. Lignin Biodegradation with Ligninolytic Bacterial Strain and Comparison of Bacillus subtilis and Bacillus sp. Isolated from Egyptian Soil. AmericanEurasian J. Agric. \& Environ. Sci., 5 (1): 39-44. ISSN 18186769.

Abo-State, M. A., Ragab, A. M. E., Sh. EL-Gendy, N., Farahat, L. A., and Madian, H. R. 2014. Bioethanol Production from Rice Straw Enzymatically Saccharified by Fungal Isolates, Trichoderma viride F94 and Aspergillus terreus F98. Soft, 3:1929.doi.org/10.4236/soft.2014.320 03

Abou-El-Enin, O. H., Fadel, J. G., and Mackill, D. J. 1999. Differences in chemical composition and fibre digestion of rice straw with, without, anhydrous ammonia from 53 rice varieties. Anim. Feed Sci. Technol., 79:129-136. ISSN $\underline{0377-8401}$

Aganga, A.A., and Tshwenyane, S. 2004. Potentials of Guinea Grass (Panicum Maximum) as Forage Crop in Livestock Production. Pakistan Journal of Nutrition 3 (1): 1-4. DOI : 10.3923/pjn.2004.1.4.

Agbagla-Dohnani, A., Noziere, P., Gaillard-Martinie, B., Puard, M., and Doreau. M. 2003. Effect of silica content on rice straw ruminal degradation. J. Anim. Sci. 140:183-192.

DOI: https://doi.org/10.1017/S00 21859603003034

Alam, M. K., Ogata, Y., Sato, Y., and Sano H. 2016. Effects of Rice Straw Supplemented with Urea and Molasses on Intermediary Metabolism of Plasma Glucose and Leucine in Sheep. Asian Australas. J. Anim. Sci. 29:523529.

DOI: https://doi.org/10.5713/ajas $\underline{.15 .0358}$

Ali, M. 1998. Peningkatan mutu nutrisi sekam padi untuk ruminansia melalui hidrolisis ganda menggunakan kapur dan asam cuka. Thesis Program Pancasarjana Institut Pertanian Bogor, Bogor

Amin, M., Hasan, S.D., Yanuarianto, O., and Iqbal, M. 2015. Pengaruh Lama Fermentasi Terhadap Kualitas Jerami Padi Amoniasi yang Ditambah Probiotik Bacillus Sp. Jurnal Ilmu dan Teknologi Peternakan Indonesia, 1 (1) : 8 - 13. ISSN : 2460-6669

Anam, N. K., Pujaningsih, R. I., dan Prasetiyono. B. W. H. E. 2012. Kadar Neutral Detergent Fiber Dan Acid Detergent Fiber Pada Jerami Padi Dan Jerami Jagung Yang Difermentasi Isi Rumen Kerbau. Animal Agriculture Journal, 1. (2): 352-361

Ansah, T., Osafo, E.L.K., and Hansen, H. H. 2010. Herbage yield and chemical composition of four varieties of Napier (Pennisetum purpureum) grass harvested at three different days after planting Agric. Biol. J. N. Am., 1(5): 923929.

doi:10.5251/abjna.2010.1.5.923. 929

Antongiovanni, M., and Sargentini, C. 1991. Variability in Chemical Composition of Straws. OptionsMediterraneennes. Serie A: 
Seminaires Mediterraneens, 4953.

Antonius, 2010. Pengaruh Pemberian Jerami Padi Terfermentasi Terhadap Palatabilitas Kecernaan Serat Dan Digestible Energy Ransum Sapi. Seminar Nasional Teknologi Peternakan dan Veteriner.

Antonius. 2009. Potensi Jerami Padi Hasil Fermentasi ProbionSebagai Bahan Pakan Dalam Ransum Sapi Simmental. Seminar Nasional Teknologi Peternakan dan Veteriner. 240-245

Arora S. 1989. Pencernaan Mikroba pada Ruminansia, Terjemahan, Judul Asli: Microbial Digestion in Ruminants, Penerjemah $\mathrm{Mu}-$ warni R., Gadjah Mada University Press. Yogyakarta.

Astutik, S. I. B., Arifin S. M., Dan Dilaga, W. 2002. Respon Produksi Sapi Peranakan Ongole Berbasis Pakan Jerami Padi Terhadap Berbagai Formula "Urea Molasses Block". Seminar Nasional Teknologi Peternakan dan Veteriner.

Bainton, S.J., Plumb, V.E., Drake, M.D., Juliano, B.O., Perez, C.M., Roxas, D.B., Kush, Lc. Dejesus, G.S., and Gomez, K.A. 1991. Variation in the nutritional value of rice straw. Anim. Feed Sci. and Tech. 34 (3-4): 261-277. doi.org/10.1016/03778401(91)90116-A

Balasubramanian, M.K. 2013. Potential utilization of rice straw for ethanol production by sequential fermentation of cellulose and xylose using Saccharomyces cerevisiae and Pachysolen tannophi- lus. International Journal of Science, Engineering, Technology and Research 2 (7): 1531-1535. ISSN: $2278-7798$

Bata, M., dan Hidayat, N. 2010. Penambahan Molases Untuk Meningkatkan Kualitas Amoniasi Jerami Padi dan Pengaruhnya terhadap Produk Fermentasi Rumen Secara In-Vitro. Agripet, 10 (2): 27-33.

Bata, M. 2008. Pengaruh Molases Pada Amoniasi Jerami Padi Menggunakan Urea Terhadap Kecernaan Bahan Kering dan Bahan Organik In Vitro . Agripet, 8 (2): 15-20.

Binod, P., Sindhu, R, Singhania, R.R., Vikram, S., Devi, L., Nagalakshmi, S., Kurien, N., Sukumaran, R.K., and Pandey, A. 2010. Bioethanol production from rice straw: an overview. Bioresource Technology. 101(13): 4767-74. DOI: 10.1016/j.biortech.2009.10.079

Castillo, L. S., Roxas, D. B., Chavez, M. A., Momongan, V. G., And Ranjhan, S. K. 1982. The effects of a concentrate supplement and of chopping and soaking rice straw on its voluntary intake by carabaos. In "The Utilization of Fibrous Agricultural Residues as Animal Feeds", :74-80, editor P. T. Doyle. School of Agriculture and Forestry, University of Melbourne, Parkville, Victoria.

Chairunnisa, C., Hanum, H., dan Mukhlis. 2013. Peran Beberapa Bahan Silikat (Si) Dan Pupuk Fosfat (P) Dalam Memperbaiki Sifat Kimia Tanah Andisol Dan Pertumbuhan Tanaman. Jurnal 
Online Agroekoteknologi, 1 (3): 732-743. ISSN No. 2337- 6597

Chellapandian, M., Arulnathan, N., and Thirumeignanam, D. 2016. Chemical Composition Of Tree Leaves For Small Ruminants In Southern Tamilnadu. International Journal of Science, Environment and Technology, 5 (3):1303 - 1305 .

Crampton, E. W., and Haris, L. E. 1969. Applied Animal Nutrition E, d. 1 st The Engsminger Publishing Company, California, U. S. A.

Dewi. 2002. Hidrolisis Limbah Hasil Pertanian Secara Enzimatik. $J$. Akta Agrosia. 5 (2): 67- 71

Dijkstra, J. and Tamminga, S. 1995. Simulation of the effects of diet on the contribution of rumen protozoa to degradation of fibre in the rumen. Br. J. Nutr. 74 (5): 617-634.

DOI: https://doi.org/10.1079/BJ $\underline{\mathrm{N} 19950166}$

Doyle, P.T., Devendra, C., and Pearce, G.R. 1996. Rice straw as a feed for ruminants. International Development Program of Australian Universities and Colleges Limited (IDP), Canberra, Australia.

Engsminger, M. E., and Olentine, C. G. 1980. Feed and Nutrition. 1 st Ed. The Engsminger Publishing Company. California. U. S. A.

Eun, J.S., Beauchemin, K.A., Hong, S.H., and Bauer, M.W. 2006. Exogenous enzymes added to untreated or ammoniated rice straw : Effect on in vitro fermentation characteristic and degradability. J. Anim. Sci. and Tech, 131: 86-101. doi:10.1016/j.anifeedsci.2006.01. 026

Fahey, G.C., Bourquin, L.D., Titgemeyer, E.C., and Atwell, D.G. 1993. Postharvest treatment of fibrous feedstuffs to improve their nutritive value. P. 715-766 in Forage Cell Wall Structure and Digestibility. H.G. Jung, D.R. Buxton, R.D. Hatfield, and J. Ralph, ed. ASA-CSSA-SSSA, Madison, WI.

Fernandez, F. D., Ramos, A. K. B., Jank, L., Carvalho, M. A., Martha Jr, G. B., and Braga, G. J. 2014. Forage yield and nutritive value of Panicum maximum genotypes in the Brazilian savannah. Sci. Agric. 71(1): 23-29. http://dx.doi.org/10.1590/S010390162014000100003

Filho, E. S. C., Muniz, E. N., de Albuquerque Range, J. H., de Arruda Santos, G. R., Neto, J. A. S., de Araujo, H. R. 2016. Dry matter yield and bromatological composition of gliricidia in different crop densities. Ciência Rural, Santa Maria, 46 (6): 1038-1043. doi.org/10.1590/0103$8478 \mathrm{cr} 20150782$

Firmani, U., Cahyoko, Y., and Mustikoweni. 2015. Utilization Turi Leaf Meal (Sesbania Grandiflora Pers.) in the Feed on the Protein Retention, Fat Retention and Energy Retention of Black Tilapia (Oreochromis Niloticus).International Journal of Science Technology \& Engineering. 2 (07): 242-244. ISSN (online): 2349-784X

Ghaffar, S.H, and Fan, M. 2014. Lignin in straw and its applications as an adhesive. International Journal 
of Adhesion \& Adhesives 48 :9210.

Greenland, D. J. 1984. Upland rice. Outlook on Agriculture, 14: 2126.

Gunam, I.B.W., and Antara, N.S. 1999. Study on Sodium Hydroxide Treatment of Corn Stalk to Increase Its Cellulose Saccharification Enzymatically by Using Culture Filtrate of Trichoderma reesei. Gitayana Agric. Technol. J. 5 (1): 34-38.

Hanum, Z., dan Usman, Y. 2011. Analisis Proksimat Amoniasi Jerami Padi Dengan Penambahan Isi Rumen. Agripet, 11(1):39-45.

Harun, S., and Geok, S.K. 2016. Effect of Sodium Hydroxide Pretreatment on Rice Straw Composition. Indian Journal of Science and Technology, 9(21):1-9 DOI: 10.17485/ijst/2016/v9i21/95245.

Hassen, A., Rethman, N.F.G., Van Niekerk, W.A., And Tjelele, T.J. 2007. Influence of season/year and species on chemical composition and in vitro digestibility of five Indigofera accessions. Anim. Feed Sci. Tech. 136 (3-4): 312 322.

DOI: http://dx.doi.org/10.1016/j. anifeedsci.2006.09.010

Hatakka, A. 2000. Biodegration of Lignin. University of Helsinki, Viikki Biocenter, Department of Applied Chemistry dan Microbiology. Helsinki.

Hau, D. K. M., Nenobais, J., Nulik, N., dan Katipana. G.F. 2005. Pengaruh Probiotik Terhadap Kemampuan Cerna Mikroba Rumen Sapi Bali. Seminar Na- sional Teknologi Peternakan dan Veteriner.

Helal, G. A. 2005. Bioconversion of straw into improved fodder: Mycoprotein production and cellulolytic activity of rice straw decomposing fungi. Mycobiology 33 (2): 90-96. doi: $10.4489 / \mathrm{MYCO} .2005 .33 .2$. $\underline{090}$

Helal, G. A. 2006. Bioconversion of Straw into Improved Fodder: Preliminary Treatment of Rice Straw Using Mechanical, Chemical and/or Gamma Irradiation. Mycobiology 34(1): 14-21. doi: 10.4489/MYCO.2006.34.1. $\underline{014}$

Howard, R., Abotsi, E.E., Jansen, L., and Howard, S. 2003. Lignocellulose biotechnology: Issues of bioconversion and enzyme production. African Journal of Biotechnology 2 (12): 602-619.

Ismail, C.H., Shajarutulwardah, M.Y., Arif, A. I., Shahida, H., Najib, M. Y., Helda, S. 2013. Keperluan pembajaan baka padi berhasil tinggi. Persidangan Padi Kebangsaan 2013. Seberang Jaya,Pulau Pinang.

Jafari, M.A, Nikkhah, A, Sadeghi, A.A., and Chamani, M.2007. The effect of Pleurotus spp. fungi on chemical composition and in vitro digestibility of rice straw. Pak J Biol Sci. 10(15):2460-2464. PMID:19070114

Jahromi, M. F., Liang, J. B., Rosfarizan, M., Goh, Y. M., Shokryazdan, P., and Ho, Y. W. 2010. Effects of Aspergillus niger (K8) on nutritive value of rice straw. African Journal of Bi- 
otechnology, 9(42): :7043-7047. DOI: 0.5897/AJB10.231

Jalaludin, S. 1994. Feeding systems based on oil palm by products. Improving animal Production Systems Based on Local feed Resources. Proceeding of a Symposium 7th AAA.

Syamsu, J.A., Ali, H. M., and Yusuf, M. 2013. Application of Technology for Processing Rice Straw as Feed for Beef Cattle. International Conference on Agriculture and Biotechnology IPCBEE vol.60 () (C) (2013) IACSIT Press, Singapore DOI: 10.7763/IPCBEE. 60 (9) :43-46.

Kargbo, F.R., Xing, J., and Zhang, Y. 2009. Pretreatment for energy use of rice straw: a review. African Journal of Agricultural Research 4: 30-40. DOI:10.5897/AJAR

Karimi, K., Kheradmandinia, S., and Taherzadeh, M. J. 2006. Conversion of rice straw to sugar by diluteacid hydrolysis. Biomass $\mathrm{Bi}$ oenergy, 30: 247 -253. DOI: 10.1016/j.biombioe.2005.11.015

Kaur, K. and Phutela, U.G. 2014. Improving Paddy Straw Digestibility And Biogas Production Through Different ChemicalMicrowave Pretreatments. Agric. Sci. Digest., 34 (1) : 8 - 14. DOI10.5958/j.0976-0547.34.1.002

Kausar, H., Sariah, M., Ismail, M.R., Saud, H.M., Habib, S.H., and Berahim, Z. 2012. Development of a potential lignocellulolytic resource for rapid bioconversion of rice straw. Afr J Biotechnol, 11: 9235-9242.

DOI: 10.5897/AJB 10.212
Khatiwada, P., Ahmed, J., Sohag, M. H., Islam, K., and Azad, A. K. 2016. Isolation, Screening and Characterization of Cellulase Producing Bacterial Isolates from Municipal Solid Wastes and Rice Straw Wastes. J Bioprocess Biotech, 6 (4) : 1-5. http://dx.doi.org/10.4172/21559821.1000280

Khorsand, H., Kiayee, N., and Masoomparast, A.H. 2012. Rice Straw Ash- A Novel Source of Silica Nanoparticles. Journal of Mechanical Research and Application. 4(3): 1-9. ISSN: 22517383, eISSN: 2251-7391

Komisarczuk, S., and Durand. M. 1991. Eff ect of Mineral on Microbial Metabolism. In: J.P. Jouany (Ed). Rumen Microbial Metabolism and Ruminant Digestion. INRA Publ., Versailes.

Lakshmikant. 1990. Cellulose Degradation and Cellulose Activity of Five Cellulolytic Fungi. World Journal of Microbiology and Biotechnology 6(1): 64-66. DOI: 10.1007/BF01225357

Lamid, M, Puspaningsih, N. N. T. And Sarwoko, M. 2013. Addition of Lignocellulolytic Enzymes Into Rice Straw Improves In Vitro Rumen Fermentation Products. J. Appl. Environ. Biol. Sci., 3(9)166-171. ISSN: 2090-4274.

Li, H. Y., Xu, L., Liu, W. J., Fang, M. Q., and Wang, N. 2014. Assessment of the Nutritive Value of Whole Corn Stover and Its Morphological Fractions. Asian Australas. J. Anim. Sci. 27:194-200. DOI: https://doi.org/10.5713/ajas .2013 .13446 
Li, J., Shen, Y., and Cai, Y. 2010. Improvement of Fermentation Quality of Rice Straw Silage by Application of a Bacterial Inoculant and Glucose. Asian-Aust. J. Anim. Sci. 23(7):901-906. DOI : 10.5713/ajas.2010.90403

Little, D. A., 1986. The mineral content of ruminant feed and the potential for mineral supplementation in South East Asia with particular reference to Indonesia. In. R. M. Dixon Ed. IDP, Canberra.

Liu, J.X., and Orskov, E.R. 2000. Cellulase treatment of untreated and steam pre-treated rice straweffect on in vitro fermentation characteristics. Animal Feed Science and Technology 88: 189200.

DOI: http://dx.doi.org/10.1016/S 0377-8401(00)00218-2

Mahmood, K., Wei-jun, Y., Nazir, K., Iqbal, R.Z., and Abdullah, A.G. 2006. Study of Cellulolytic soil Fungi and Two Nova Spesies and New Medium. Journal of Zheijiang University, 7(6): 459-466. doi: $\underline{10.1631 / j z u s .2006 . B 0459}$

Malik, K., Tokkas, J., Anand, R. C., and Kumar. N. 2015. Pretreated rice straw as an improved fodder for ruminants-An overview. J. Appl. \& Nat. Sci. 7 (1) : $514-520$.

Manurung T., dan Zulbardi M. 1996. Peningkatan Mutu Jerami Padi Dengan Perlakuan Urea

Dan Tetes. Jurnal llntu Ternak dan Veteriner 2 (1) :33-38.

Marsden, W.L., and Gray, P.P. 1986. Enzymatic Hydrolysis of Cellulases in Lignocellulosic. Material. CRC. Critical Rev. in Bio- technol. Vol.3 (3): 235-276. doi.org/10.3109/0738855850915 $\underline{0785}$

Marxen, A., Klotzbücher, T., Jahn, R., Kaise, K., Nguyen, V. S., Schmidt, A.,. Schädler, M., Vetterlein, D. 2016. Interaction between silicon cycling and straw decomposition in a silicon deficient rice production system. Plant Soil 398:153-163 DOI 10.1007/s 11104-015-2645-8.

Masama, E., Topps, J.H., And Massdorp. B.V. 1997. Effects of supplementation with foliage from the tree legume Acacia angustissima, Cajanus cajan, Calliandra calothyrsus and Leucaene leucocephala on feed intake, digestibility and nitrogen metabolism of sheep given maize stover ad libitum. Anim. Feed Sci. and Tech. 69: 233 - 240. ISSN 0377-

8401 CODEN AFSTDH

Mathius, I. W., dan Sinurat. A. P. 2001. Pemanfaatan bahan pakan inkonvensional untuk ternak. Wartazoa 11 (2): 20-31.

Mayulu, H., Sunarso, M., Christiyanto, and Ballo, F. 2013. Intake and Digestibility of Cattle's Ration on Complete Feed Based-On Fermented Ammonization Rice Straw with Different Protein Level. Internat. J. of Sci. and Eng. 4(2):86-91. Doi: 10.12777/ijse.4.2.2013.86-91

McDonald, P., Edwards, R.A., and Greenhalg, J.P.D. 2002. Animal Nutrition. sixth Ed. Prentice hall. Gosport. London. Pp : 427-428.

McLennan, S. R., Wright, G. S., and Blight, G. W. 1981. Effects of 
supplements of urea, molasses and sodium sulfate on the intake and liveweight of steers fed rice straw. Australian Journal of Experimental Agriculture and Animal Husbandry 21(111): 367370.

doi.org/10.1071/EA9810367

Minson, D. J. 1963. The effect of pelleting and wafering on the feeding value of roughage - A review. Journal of the British Grassland Society 18, 39- 44.

Mirni, L., Puspaningsih, N.N.T., Chusniati, S. 2006. Penggunaan bakteri xilanolitik asal rumen sebagai inokulum pada jerami padi sebagai upaya peningkatan mutu pakan ternak ruminansia. Lembaga Penelitian. Universitas Airlangga, Surabaya. p19-25.

Mirni, L., Nugroho, T.P., Chusniati, S., dan Rochiman, K. 2011. Eksplorasi Bakteri Selulolitik Asal Cairan Rumen Sapi Potong sebagai Bahan Inokulum Limbah Pertanian. Jurnal Ilmiah Kedokteran Hewan, 4(1):37-42.

Modak, S. K. 1985. Chemical composition and dry matter and organic matter degradability of different varieties of rice straw by nylon bag technique. M. S. Thesis. Department of Animal Science, Bangladesh Agricultural University, Mymensingh, Bangladesh.

Muhakka, Riswandi, dan Irawan, A. 2014. Pengaruh Pemberian Pupuk Cair terhadap Kandungan NDF, ADF, Kalium, dan Magnesium pada Rumput Gajah Taiwan. Jurnal Peternakan Sriwijaya. 3, (1): 47-54.
Mulijanti, S.L., Tedy, S., dan Nurnayetti. 2014. Pemanfaatan Dedak Padi dan Jerami Fermentasi pada Usaha Penggemukan Sapi Potong di Jawa Barat. Jurnal Peternakan Indonesia. 16 (3): 179-187

Mustabi, J., Ngitung, R., Islamiyati, R., Akhirany, N., Natsir, A., Jusoff, K., Ismartoyo, Kuswinanti, T., and Rinduwati. 2013. Rice Straw Fermented with White Rot Fungi as an Alternative to Elephant Grass in Goat Feeds. Global Veterinaria 10 (6): 697-701. DOI: 10.5829/idosi.gv.2013.10.6.1136

Nasrullah, Niimi, M., Akashi, R., and Kawamura. O. 2003. Nuritive Evalution of Forage Plants Grown in South Sulawesi, Indonesia. Asian-Aust. J. Anim. Sci. 2003. $16 \quad$ (5) : 693-701. DOI: https://doi.org/10.5713/ajas .2003 .693

NRC, 1980. Nutrient Requirements of Beef Cattle. National Academy of Science, Washington, DC., USA.

Odedire, J. A., and Babayemi, O. J. 2008. Comparative studies on the yield and chemical composition of Panicum maximum and Andropogon gayanus as influenced by Tephrosia candida and Leucaena leucocephala Livestock Research for Rural Development 20 (2). http://www.cipav.org.co/lrrd/lrrd 20/2/oded20027.htm.

Paath, R. H., Kaligis, D. A., dan Kaunang, C. L. 2012. Produksi Dan Kualitas Jerami Jagung Sebagai Pakan Ternak Sapi Di Kabupaten Minahasa Selatan. Eugenia, 18 (1): 29-34. 
Peripolli, V., Barcellos, J.O.J., Prates, E.R., McManus, C., da Silva, L.P., Stella, L.A., Costa Jr, J.B.G., and Lopes, R.B. 2016. Nutritional value of baled rice straw for ruminant feed. R. Bras. Zootec., 45(7) :392-399. http://dx.doi.org/10.1590/S180692902016000700006

Phutela, U. G., Sahni, N., and Sooch, S. S. 2011. Fungal degradation of paddy straw for enhancing biogas production. Indian Journal of Science and Technology. 4 (6): 660-665. ISSN: 0974- 6846

Polyorach, S., and Wanapat, M. 2015. Improving the quality of rice straw by urea and calcium hydroxide on rumen ecology, microbial protein synthesis in beef cattle. Journal of Animal Physiology and Animal Nutrition 99: 449-456.

DOI: 10.1111/jpn.12253

Premaratne, S., and Perera, H.G.D. 1999. Evaluation of Provenance In Condensed Tannin Content of Fresh Leaves of Calliandra calothyrsus. Asian-AusJ. Anim. Sci. 12 (6): 891-894. DOI: https://doi.org/10.5713/ajas $\underline{.1999 .891}$

Preston, T.R., and Leng, R.A. 1987. Matching ruminant production systems with available resources in the tropics and sub-tropics. Penambul Books: Armidale, Australia.

Prihartini, I., Soebarinoto, S., Chuzaemi dan Winugroho. M. 2011. Karakteristik Nutrisi dan Degradasi Jerami Padi Fermentasi oleh Inokulum Lignolitik TLiD dan BopR. Animal Production. 11 (1): 1-7.
Rahalus, R., Tulung, B., Maaruf, K., and Wolayan. F. R. 2014. Pengaruh Penggunaan Konsentrat Dalam Pakan Rumput Benggala ( Panicum Maximum ) Terhadap Kecernaan Ndf Dan Adf Pada Kambing Lokal. Jurnal Zootek 34 (1):75-82.

Rahnama, N., Mamat, S., Shah, U.K.M., Ling, F.H., Abdul Rahman, N.A., and Ariff, A.B. 2013. Effect of Alkali Pretreatment of Rice Straw on Cellulase and Xylanase Production by local Trichoderma harzianum SNRS3under Solid State Fermentation. Bioresources 8 (2): 2881-2896. ISSN: 19302126 .

Reddy, N., and Yang Y.2006. Properties of High-Quality Long Natural Cellulose Fibers from Rice Straw. J. Agric. Food Chem., 54 (21): 8077-

8081DOI: $10.1021 / \mathrm{jf0617723}$

Relling, E.A., van Niekerk, W.A., Coertze, R.J., and. Rethman, N.F.G. 2001. An evaluation of Panicum maximum cv. Gatton: 2. The influence of stage of maturity on diet selection, intake and rumen fermentation in sheep. South African Journal of Animal Science, 31(2): 85-91. http://dx.doi.org/10.4314/sajas.v $\underline{31 \mathrm{i} 2.3833}$

Rodrigues, M.A.M., Pinto, P., Bezerra, R.M.F., Dias, A.A., Guedes, C.V.M., Gardoso, V.M.G.W., Colaco, L.M.M. J., and Sequeira, C.A. 2008. Effect of enzyme extracts isolated from white-rot fungi on chemical composition and in vitro digestibility of wheat straw. Animal Feed Science and Technology 141(3-4): 326-338. 
DOI: http://dx.doi.org/10.1016/j. anifeedsci.2007.06.015

Rusdi, R. Arief, dan Agus.2007. Pengaruh Pengeringan Daun Turi (Sesbania Grandiflora) Terhadap Degradasi Bahan Kering Dan Protein Dalam Rumen. Majalah Ilmiah peternakan. 10 (2):1-8.

Sajimin, Y. C., Rahardjo, dan Purwantari, N. D. 2004. Evaluasi produksi tanaman pakan ternak P. maximum $c v$ Riversdale dengan penggunaan manure kelinci. Seminar Nasional Klinik Teknologi pertanian sebagai basis pertumbuhan usaha agribisnis menuju petani nelayan mandiri. BPTP Sulut di Menado.

Santos, M. B., Nader, G. A., Robinson, P. H., Kiran, D., Krishnamoorthy, U., Gomes, M. J. 2010. Impact of simulated field drying on in vitro gas production and voluntary dry matter intake of rice straw. Anim Feed Sci Technol 159 (3-4): 96-104. DOI: http://dx.doi.org/10.1016/j. anifeedsci.2010.05.012

Saratale, G.D., Chen, S.D., Lo, Y.C., Saratale, R.G., and Chang, J.S. 2008. Outlook of biohydrogen production from lignocellulosic feedstock using dark fermentation-a review. J. Sci. Ind. Res. 67: 962-979.

Sarnklong, C., Cone, J. W., Pellikaan, W., and Hendriks. W. H. 2010. Utilization of Rice Straw and Different Treatments to Improve Its Feed Value for Ruminants: A Review. Asian-Aust. J. Anim. Sci. 23 (5) : 680 - 692. DOI: https://doi.org/10.5713/ajas $\underline{.2010 .80619}$
Sarwar, M., Khan, M.A., and Nisa, M. 2004. Effect of organic acids of fermentable carbohydrates on digestibility and nitrogen utilization of urea treated wheat straw in buffalo bulls. Australian Journal of Agricultural Research 55: 223-228.

Schiere, J.B., and Ibrahim, M.N.M. 1989. Feeding of urea ammonia treated rice straw: A compilation of miscellaneous reports produced by the straw utilization project, Pudoc, Wageningen, Sri Lanka.

Seglar, B. 2003. "Fermentation analysis and silage quality testing," in Proceedings of the Minnesota Dairy Health Conference. :119136, University of Minnesota.

Selçuk, Z., Çetinkaya, N. Salman, M., and Genç, B. 2016. The determination of in vitro gas production and metabolizable energy value of rice straw treated with exogenous fibrolytic enzymes. Turk $J$ Vet Anim Sci 40: 707-713. doi:10.3906/vet-1601-113.

Selim, A.S.M., Pan, J., Takano, T., Suzuki, T., Koike, S., Kobayashi, Y. and Tanaka, K. 2004. Effect of ammonia treatment on physical strength of rice straw, distribution of straw particles and particle-associated bacteria in sheep rumen. Animal Feed Science and Technology 115: 117-128. DOI: http://dx.doi.org/10.1016/j. anifeedsci.2004.01.011

Shen, H. S., Ni, D. B., and Sundstøl, F. 1998. Studies on untreated and urea-treated rice straw from three cultivation seasons: 1. Physical and chemical measurements in straw and straw fractions. Anim. 
Feed Sci. Technol. 73 (3-4):243261.

http://doi.org/10.1016/S0377$\underline{\text { 8401(98)00157-6 }}$

Soenarjo, E., Damardjati, D.S., dan Syam. M. 1991. Padi Buku 3 . Badan Penelitian dan Pengembangan Pertanian. Pusat Penelitian dan Pengembangan Tanaman Pangan. Bogor

Soepranianondo, K., Nazar, D. S., dan Handiyatno, D. 2007. Potensi Jerami Padi yang Diamoniasi dan Difermentasi Menggunakan Bakteri Selulolitik terhadap Konsumsi Bahan Kering, Kenaikan Berat Badan dan Konversi Pakan Domba. Media Kedokteran Hewan. 23 (3) :202-205.

Stanbury, P.F., and Whitaker, A. 1984. Principle of Fermentation Technology. Pergamon Press Ltd, England.

Sudana. 1984. "Straw Basal Diet for Growing Lambs" (A Thesis Submitted to the Degree of Master of Science). The Department of Biochemistry and Nutrition, the University of New England, Armidale, N. S. W., 23451, Australia.

Sudirman, dan Imran. 2007. Kerbau Sumbawa: sebagai konverter sejati pakan berserat. Lokakarya Nasional Usaha Ternak Kerbau Mendukung Program Kecukupan Daging Sapi. Fakultas Peternakan Universitas Mataram, Nusa Tenggara Barat.

Sudirman, Suhubdy, S. D., Hasan, S. H., Dilaga, dan Karda, I. W. 2015. Kandungan Neutral Detergent Fibre (NDF) dan Acid Detergent Fibre (ADF) Bahan
Pakan Lokal Ternak Sapi yang Dipelihara pada Kandang Kelompok . Jurnal Ilmu dan Teknologi Peternakan Indonesia 1 (1) : 66-70

Syamsu, J.A., Natsir, A., Siswadi., Abustam, E., Hikmah, Nurlaelah, Muliwarni, Setiawan, A.H., dan Arasy, A.M. 2006. Limbah Tanaman Pangan sebagai Sumber Pakan Ruminansia: Potensi dan Daya Dukung di Sulawesi Selatan. Makassar: Yayasan Citra Emulsi dan Dinas Peternakan Propinsi Sulawesi Selatan.

Tanuwiria, U. H., Ayuningsih, B., dan Mansyur. 2005. Fermentabilitas Dan Kecernaan Ransum Lengkap Sapi Perah Berbasis Jerami Padi Dan Pucuk Tebu Teramoniasi (In Vitro) Jurnal Ilmu Ternak, 5 (2): $64-69$.

Tillman, D.A., Hartadi, H., Reksohadiprodjo, S., Lebdosoekojo, S.1998. Ilmu Makanan Ternak Dasar. Gadjah Mada University Press, Yogyakarta.

Trisnadewi, A. A. A. S., Sumardani, N. L. G., Tanama Putri, B. R. I, Cakra, G. L. O., dan Aryani. I G. A. I. 2011. Peningkatan Kualitas Jerami Padi Melalui Penerapan Teknologi Amoniasi Urea Sebagai Pakan Sapi Berkualitas Di Desa Bebalang Kabupaten Bangli. Udayana Mengabdi 10 (2): 72 - 74 ISSN : 1412-0925.

Ukanwoko, A.I. and Igwe, N.C. 2012. Proximate Composition of Some Grass and Legume Silages Prepared in a Humid Tropical Environment. Int. Res. J. Agric. Sci. Soil Sci. 2(2) : 068-071. (ISSN: 2251-0044) 
Vadiveloo, J. 2003. The effect of agronomic improvement and urea treatment on the nutritional value of Malaysian rice straw varieties. Anim. Feed Sci. Technol. 108 (14):33-146.

http://doi.org/10.1016/S0377$\underline{8401(03) 00170-6}$

Van Soest, P. 2006. Rice Straw, the Role of Silica and Treatments to Improve Quality. Animal Feed Science and Technology, 130 (14):137-171.

http://doi.org/10.1016/j.anifeedsc i.2006.01.023

Van Soest, P. J. 1982. Nutritional Ecology of The Ruminant Metabolism Chemistry and Forage and Plant Fiber. Cornell University. Oregon. USA.

Van Soest, P.J . 1983. Nutritional Ecology of the Ruminant. O\&B Books, Inc . Corvalis, Oregon

Vanholme, R., Demedts, B., Morreel, K., Ralph, J., and Boerjan, W. 2010. Lignin Biosynthesis and Structure. Plant Physiology. 153 (3):895-905. doi: http://dx.doi. org/10.1104/pp.110.155119

Vijchulata, P., and Sanpote, S. 1982. Changes in the nutritive value of rice straw after growth of Volvariella volvacea fungus. In "The Utilization of Fibrous Agricultural Residues as Animal Feeds". :113-118, ed. P. T. Doyle. (School of Agriculture and Forestry, University of Melbourne, Parkville, Victoria).

Wanapat, M., Kang, S., Hankla, N., and Phesatcha, K. 2013. Effect of rice straw treatment on feed intake, rumen fermentation and milk production in lactating dairy cows. Afr. J. Agric. Res. 8(17):1677-1687. DOI: 10.5897/AJAR2013.6732

Wati, N. E., Achmadi, J., dan Pangestu, E. 2012. Degradasi Nutrien Bahan Pakan Limbah Pertanian Dalam Rumen Kambing Secara In Sacco (In Sacco Ruminal Degradation of Nutrients of Agricultural By-products in the Goat). Animal Agriculture Journal, 1. (1): 485 - 498 .

White, T.W. And F.G. Hembry. 1985. Rice by-products in ruminant rations. La. Agr. Exp. Sta. Bull. No. 771: 18.

Winugroho, M. 1999. Nutritive Values of Feed Ingredient in TropicsReview. Asian-AusJ. Anim. Sci. 12

493-502. doi: https://doi.org/10.5713/ajas. 1999.493

Wongsrikeao, W., And Wanapat, M. 1985. The effects of urea treatment of rite straw on the feed intake and liveweight gain of buffaloes. In "The Utilization of Fibrous Agricultural Residues as Animal Feeds", pp. 81-84, ed., P. T. Doyle. Canberra.

Xiong, X. Q., Liao, H. D., Ma, J. S., Liu,X. M., Zhang, L. Y., Shi, X. W., Yang, X. L., Lu, X. N., and Zhu, Y. H. 2013. Isolation of a rice endophytic bacterium, Pantoea sp. Sd-1, with ligninolytic activity and characterization of its rice straw degradation ability. Letters in Applied Microbiology 58 (2): 123-129. doi:10.1111/lam.12163.

Yang, J.S., Yuan, H.L., Wang, H.X., and Chen, W.X. 2005. Purification and characterization of lig- 
nin peroxidases from Penicillium decumbens P6. World Journal of Microbiology and Biotechnology. 21 (4) :435-440. DOI: 10.1007/s11274-004-1876-2

Yanuarianto, O., M. Amin, M. Iqbal, S. D. Hasan. 2015. Kecernaan Bahan Kering dan Bahan Organik Jerami Padi yang Difermentasi dengan Kombinasi Kapur Tohor, Bacillus s., dan Air Kelapa pada Waktu yang Berbeda. Jurnal Ilmu dan Teknologi Peternakan Indonesia. 1 (1) : 47-52.

Yanuartono, Indarjulianto,S., Purnamaningsih, H., and Raharjo,S. 2016. Evaluasi Klinis dan Laboratoris pada Kejadian Sapi Ambruk Tahun III. Laporan Penelitian. Penelitian Unggulan Perguruan Tinggi (PUPT), Kementrian Riset, Teknologi, dan Pendidikan Tinggi.

Yuan, X.J., Dong, Z.H., Desta, S.T., Wen, A.Y., Zhu, X., Rong, T., Shao, T. 2016. Adding distiller's grains and molasses on fermentation quality of rice straw silages. Ciência Rural, Santa Maria, 46 (12): 2235-2240. http://dx.doi.org/10.1590/0103$8478 \mathrm{cr} 20150851$

Yulianti, A. 2010. Kinetika Volatile Fatty Acid (Vfa) Cairan Rumen Dan Estimasi Sintesis Protein Mikrobia Pada Sapi Perah Dara Peranakan Friesian Holstein Yang Diberi Pakan Basal Rumput Raja, Jerami Jagung, Dan Jerami Padi Yang Disuplementasi Konsentrat Protein Tinggi. Jurnal Teknologi Pertanian 6(1) :25-33.
Zakaria, Y., Novita, C. I., dan Samadi. 2013. Efectivitas Fermentasi dengan Sumber Substrat yang Berbeda Terhadap Kualitas Jerami Padi. Agripet 13 (1):22-25.

Zeng, G. M., Yu, H.Y., Huang, H.L., Huang, D.L., Chen, Y.N., Huang, G.H., and Li, J.B.2006. Laccase activities of a soil fungus Penicillium simplicissimum in relation to lignin degradation. World Journal of Microbiology and Biotechnology. 22(4): 317-324. DOI: $10.1007 / \mathrm{s} 11274-005-9025-$ 0

Zhao, H, Yu, H., Yuan, X., Piao, R., Li, H., Wang, X., and Cui, Z. 2014. Degradation of Lignocelluloses in Rice Straw by BMC-9, a Composite Microbial System. J. Microbiol. Biotechnol., 24 (5): 585-591.

10.4014/jmb.1310.10089 
Zhaoa, X. G., M. Wanga, Z. L. Tan, S. X. Tang, Z. H. Sun, C. S. Zhou and X. F. Han.2009. Effects of Rice Straw Particle Size on Chewing Activity, Feed Intake, Rumen Fermentation and Digestion in Goats. Asian-Aust. J. Anim. Sci. 22(9):1256-1266. doi: https://doi.org/10.5713/ajas. 2009.80672

Zulbardi, M., Siregar, A.R., dan Mathius, I.W. 1983. Jerami padi dengan jagung dan dedak padi sebagai makanan kerbau. Pros. Pertemuan Ilmiah Ruminansia Besar. Cisarua, 6 - 9 September 1982. Puslitbang Peternakan, Bogor. 33 - 36. 